\title{
CASH-CROP PRODUCTION IN ZIMBABWE: POSSIBLE STRATEGIES TO SUSTAINABLY REVIVE THE COTTON AND TOBACCO INDUSTRIES
}

\author{
Talknice Saungweme \\ Great Zimbabwe University, Zimbabwe \\ E-mail: talknice2009@gmail.com
}

\begin{abstract}
Agricultural activities are critical elements in determining the level and pace of sustainable economic development in Zimbabwe. Cash crop production, in particular, has made significant strides in social and economic developments in most developing countries. Besides being the major agricultural export crops, tobacco and cotton have facilitated the growth of forward manufacturing industries, whose contribution to the economy remains noticeable and critical. However, after the year 2000, the aggregate contribution of these prime crops declined, leading to the collapse of related downstream industries, and an increase in poverty levels in some communities. Henceforth, this paper visited cotton and tobacco production levels with the focus of suggesting possible strategies and polices that can be instituted to sustainably revive these industries in Zimbabwe.
\end{abstract}

\section{KEY WORDS}

Cotton-to-clothing; Backward/forward linkages; Contract farming, Strategic farms.

Cotton husbandry in Zimbabwe is principally done on both small-and-large scales. The crop is primarily grown in the western and northern parts of the country; mainly Gokwe, Sanyati, Guruve, Muzarabani, Mt Darwin, Chinhoyi, Mazowe, Rafingora, Checheche and Triangle. Small-scale cotton production is mostly done to generate income for subsistence purposes, while large-scale is for feeding into processing industries and ultimately exports. Following poor quantity and quality deliveries to processing organisations, most cotton buying institutions reverted to backward linkages, which resulted in adoption of contract cotton farming in most areas across the country. Apart from droughts, successive poor marketing and pricing models and policies on the market, led to the incessant contraction of the cotton production sector.

Cotton production and the economy of Zimbabwe. Cotton production was remarkably known source of foreign currency to Zimbabwe. In addition, existence, survival and development of the textile, oil pressing and stock-feed industries were/are purely dependent on cotton production. In secular platforms, cotton is referred to as the white gold, owing to the associated economic benefits that accrue to societies and the country. The growth and sell of cotton was one strategy by the country to alleviate poverty in communal areas, especial in semi arid areas - ecological agricultural zone three. Rural developments, employment creation and export earnings are notable positive gains from cotton production; communities like Gokwe, Sanyati, Rushinga, Checheche, Muzarabani and Matepatepa in Bindura are a testimony to this fact.

In 1992, cotton-related products contributed about 19 percent $^{1}$ of the country's aggregate agricultural export earnings. The cotton sector was a key source of livelihood for over one million people until 2003, including farmers, farm workers and the textile industry employees. However, the period after 2004 was characterised by cotton production irregularities, with a decline in both quality and quantity. The following graph shows disaggregated cotton exports for the years 2005 to 2010 .

Critical to note in figure one above is the persistent ups-and-downs of cotton lint and textile exports over successive years. The pattern is testimony to market price uncertainties. When cotton buying prices were low in the current selling season, farmers will shun the crop in the subsequent season. With few farmers and little deliveries in the following year, the buyers will bid for the limited supply thus pushing up prices. More farmers will again be lured

\footnotetext{
${ }^{1}$ Ndlela and Robinson 1992 in the Country Report for the United Nations University
} 
into the industry in the successive season leading to large deliveries that ultimately push prices down. Such fluctuations could not guarantee a stable cotton-to-clothing industry.

Figure 1 - Cotton industry export composition*

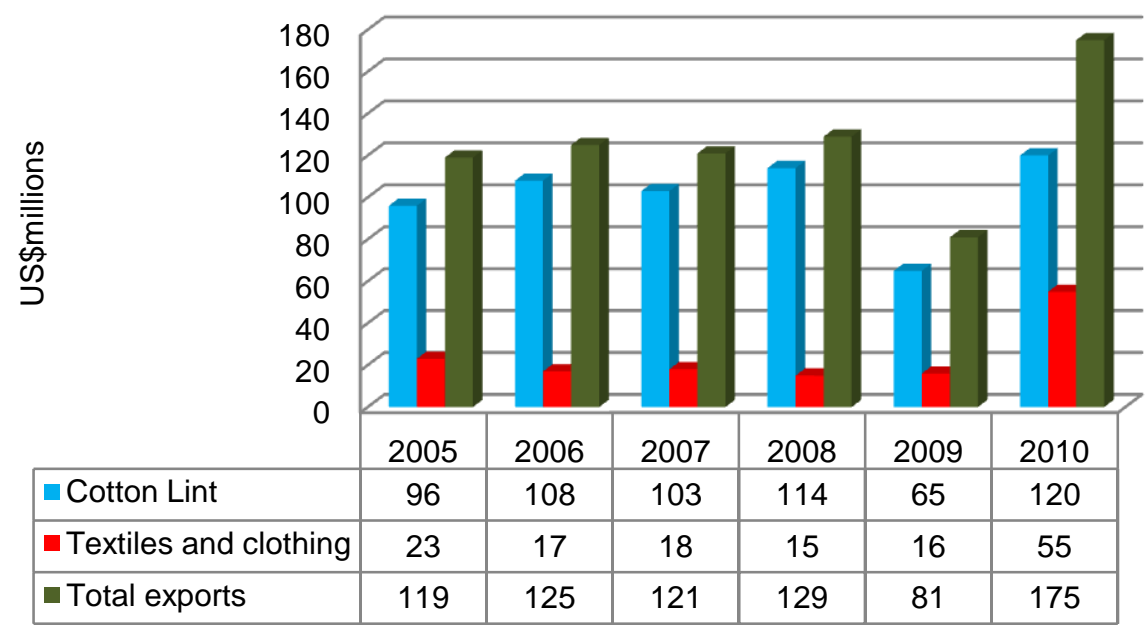

* Source: ZEPARU Occasional Research Paper No.1/2014

Evident, as well, in the figure above are the low export volumes for the cotton industry itself, for example $\$ 81$ million in 2009. These low export figures are a sign of a depressed cotton industry and also a cause of the huge volumes of clothing imports from Asian countries and neighbouring countries, such as Zambia and South Africa. The portrayed pattern in figure one above is also one explanation to high formal unemployment rates in the country, owing to the contraction of the whole cotton-to-clothing value chain.

Table 1 - Quantities of cotton exports from 2005 to 2014

\begin{tabular}{|c|c|c|c|c|c|c|c|c|c|c|c|}
\hline $\begin{array}{l}\mathrm{HS} \\
\text { code }\end{array}$ & $\begin{array}{l}\text { Cotton export } \\
\text { description }\end{array}$ & 2005 & 2006 & 2007 & 2008 & 2009 & 2010 & 2011 & 2012 & 2013 & 2014 \\
\hline 5201 & $\begin{array}{l}\text { Cotton, not carded } \\
\text { or combed }\end{array}$ & 68,926 & 72,721 & 74,314 & 75,025 & 89,651 & 84,553 & 89,466 & 132,371 & 58,391 & 40,041 \\
\hline 5205 & $\begin{array}{l}\text { Cotton yarn (not } \\
\text { sewing thread) } \\
85 \% \text { or more } \\
\text { cotton, not retail }\end{array}$ & 3,550 & 6,502 & 5,891 & 3,991 & 3,341 & 2,455 & 1,716 & 3,706 & 5,047 & 3,267 \\
\hline 5209 & $\begin{array}{c}\text { Woven cotton } \\
\text { fabrics, } 85 \% \text { or } \\
\text { more cotton, } \\
\text { weight over } 200 \\
\mathrm{~g} / \mathrm{m} 2\end{array}$ & 818 & 1,110 & 565 & 979 & 1,118 & 1,228 & 484 & 917 & 812 & 510 \\
\hline 5202 & $\begin{array}{l}\text { Cotton waste } \\
\text { (including yarn } \\
\text { waste and } \\
\text { garnetted stock) }\end{array}$ & 140 & 416 & 357 & 565 & 414 & 395 & 521 & 2,427 & 710 & 252 \\
\hline 5208 & $\begin{array}{l}\text { Woven cotton } \\
\text { fabrics, } 85 \% \text { or } \\
\text { more cotton, } \\
\text { weight less than } \\
200 \mathrm{~g} / \mathrm{m} 2 \\
\end{array}$ & 196 & 281 & 164 & 302 & 164 & 282 & 133 & 119 & 89 & 62 \\
\hline 5212 & $\begin{array}{l}\text { Woven fabrics of } \\
\text { cotton }\end{array}$ & 1 & 2 & & 1 & - & 2 & - & - & - & 12 \\
\hline 5203 & $\begin{array}{l}\text { Cotton, carded or } \\
\text { combed }\end{array}$ & 437 & 329 & 13 & & & 1,869 & 88 & 86 & 2 & 5 \\
\hline 5204 & $\begin{array}{l}\text { Cotton sewing } \\
\text { thread }\end{array}$ & & & 3 & & 96 & & & - & 108 & \\
\hline - & $\begin{array}{l}\text { Other cotton } \\
\text { products }\end{array}$ & 23 & 49 & - & 43 & 13 & 3 & 10 & 1 & - & \\
\hline \multicolumn{2}{|r|}{ Total (in tons) } & 74,091 & 81,410 & 81,307 & 80,906 & 94,797 & 90,787 & 92,418 & 139,627 & 65,159 & 44,149 \\
\hline
\end{tabular}

Sources: ITC calculations based on UN COMTRADE statistics 
The table 1 shows the quantities of cotton exports from 2005 to 2014 . Besides exportation of raw cotton, there is affirmation of a contracting cotton industry, especially in the multicurrency period, beginning 2009, and worsened in 2013 and 2014.

Cotton marketing in Zimbabwe. Cotton marketing, since independence until 1994, was predominantly the responsibility of the central government. The Cotton Marketing Board (CMB) had the sole national mandate of buying, ginning, selling and exporting all cotton related outputs, like lint, cotton seed, cotton oil and animal feed. Cotton pricing was centrally gazetted by the government and reviewed every selling season. However, in 1991, the government of Zimbabwe adopted a series of capitalism-oriented policies, which gave birth to major economic and social structural reforms. Such reforms led to the privatisation of CMB in 1994, which changed name to Cotton Company of Zimbabwe Limited (Cottco). Following this liberalisation and the 2009 deregulation, other private players joined the market, and thus increased the demand for cotton, with market forces and future-farming-contracts determining the buying-and-selling prices. Figure 2 below provides evidence of successively increasing cotton production levels for the period 1995 to 2000 and a systematic decline from 2004 to 2009.

Figure 2 - Cotton production levels from 1995 to 2010*

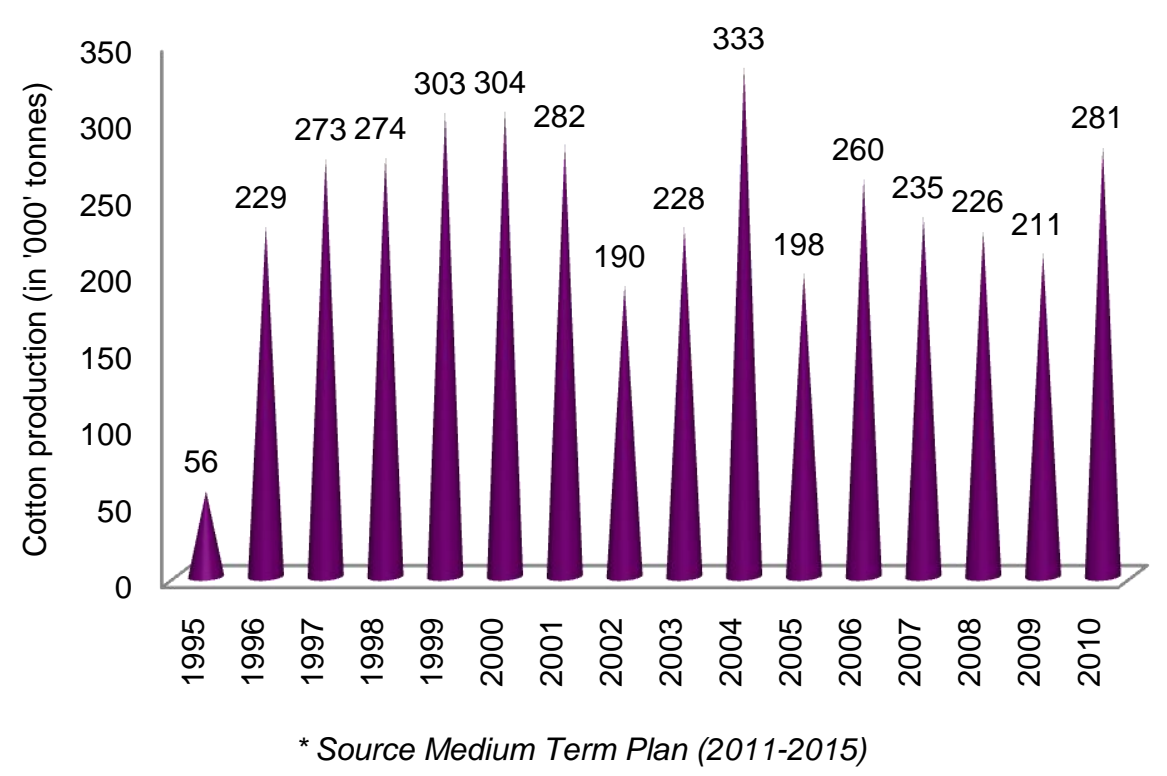

Evident also in figure two above are the decline and systematic up-and-downs in cotton production levels, successively from 2001 to 2010. As noted earlier, a chain of cotton market conditions uncertainty (especially prices) drove some farmers out of the industry, with some reducing their crop hectarage or venturing into other agricultural activities, like gardening (horticulture). According to the ZEPARU OCCASIONAL RESEARCH PAPER No.1/2014, "Production of cotton on the farms slumped from $350703 \mathrm{mt}$ in 2011-12 to $143849 \mathrm{mt}$ in 2012-13, a 59\% drop in just a single season. Exports of lint similarly declined during the same period from $139615 \mathrm{mt}$ in 2011-12 to $59000 \mathrm{mt}$ in 2012-13, again a very sharp drop of $80615 \mathrm{mt}$, or $57.7 \%$ ". These low cotton productions by both small-scale and commercial farmers adversely affect processing industries. For instance, David Whitehead which started operations in November 2014 (after four years of non-business) is operating at between 35$40 \%$, same with Irazim in Chitungwiza. Given the contribution of the cotton-to-clothing industry to national development through employment creation, exports and social welfare, it becomes apparent for all stakeholders to actively participate in the rejuvenation of this sector. 
Tobacco farming in Zimbabwe. Tobacco is Zimbabwe's top export cash crop. Tobacco farming was predominantly done by white commercial farmers prior to the government land reform programme of 2000 , supplying over $95 \%$ of tobacco to the auction floors. After the land redistribution exercise, however, small scale tobacco farmers are now accounting close to $85 \%$ of tobacco deliveries on the auction floors, with the difference being accounted by semi-commercial and commercial farms. Virginia flue-cured, burley, oriental and dark-air cured tobacco resistances are the four major tobacco varieties grown across Zimbabwe, with virginia and burley being the most, accounting for over $90 \%$ of tobacco production.

Comparison of tobacco and cotton production in Zimbabwe (1995-2010). The volumes of tobacco deliveries to the auction floors between 1995 and 2000 were on average above 191 000 tonnes. The highest tobacco production was in 1998, reaching a record high of 226000 tonnes. Unlike cotton whose production was fluctuation over the years, tobacco output persistently declined to a record low of only 55000 tonnes in 2006. The combination of successive decline in cotton and tobacco production between 2007 and 2009, worsened the country's foreign exchange position, increased unemployment of all factors of production and adversely affected the general livelihoods of the general households.

Figure 3 - A comparison of tobacco and cotton production in Zimbabwe (1995-2010)*

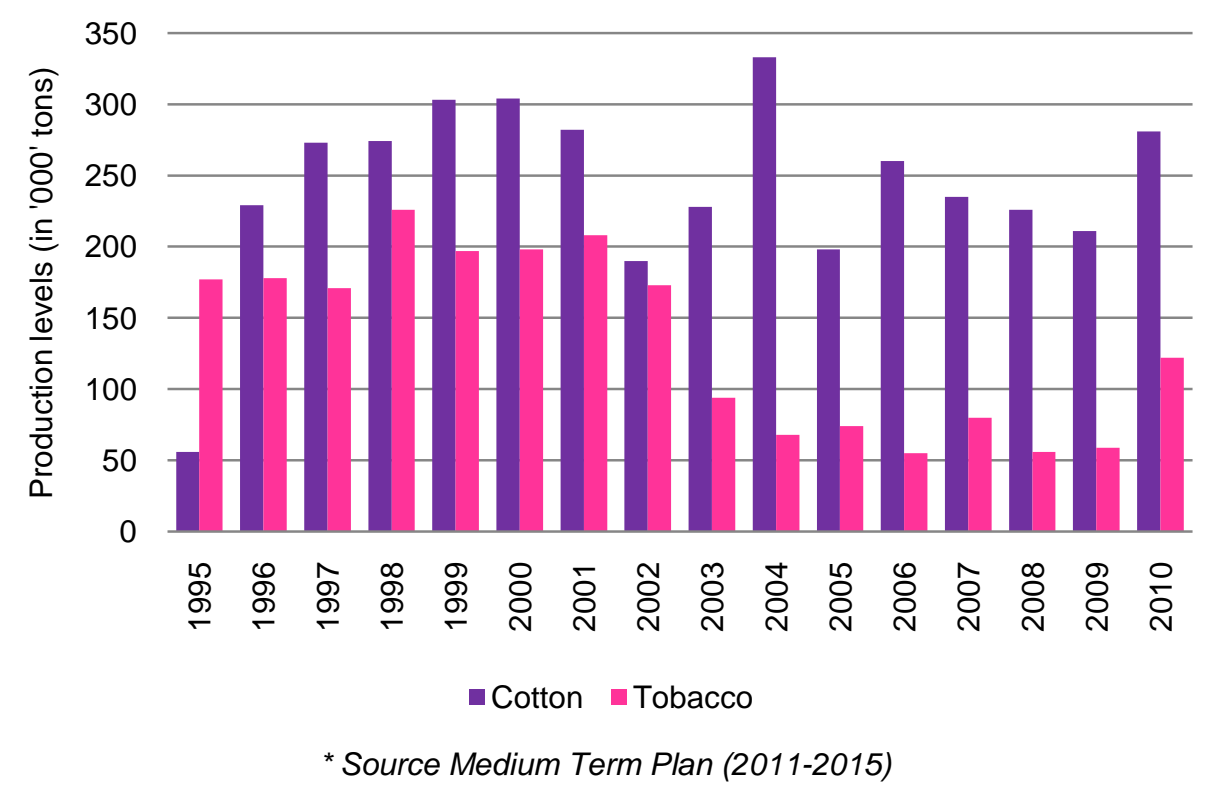

Tobacco marketing and export destinations. Beginning 1936, during the colonial era, tobacco purchases, processing and selling (including exporting) was purely the mandate of the Tobacco Marketing Board (TMB). In 1997, TMB was re-constituted and it changed name to Tobacco Industry and Marketing Board, and tobacco selling was now done via the auction floor system. By 2004, a dual tobacco marketing system was adopted, with the introduction of contract-growing-and-marketing structure.

The table two below summarises Zimbabwe's top six export destinations from 2010 to 2014. South Africa (90.2\%) and Mozambique (7.6\%) are Zimbabwe's largest tobacco export markets, with Mozambique being the fastest growing market. These statistics provides a basis for further research as to why Mozambique is buying tobacco in Zimbabwe - Is it the case of tobacco processing industries in this country or there are overseas agents based in Mozambique who buy tobacco for shipping to world markets? In $2014,95,89 \%$ of the tobacco exports were unmanufactured, while $2,65 \%$ and $1.22 \%$ were cigarillos \& cigarettes and pipe, chewing \& snuff tobacco, respectively. 
Table 2 - Zimbabwe's tobacco export destinations (2010-2014)*

\begin{tabular}{|l|l|l|l|l|l|}
\hline \multicolumn{1}{|c|}{ Export destination } & \multicolumn{1}{c|}{2010} & \multicolumn{1}{c|}{2011} & \multicolumn{1}{c|}{2012} & \multicolumn{1}{c|}{2013} & \multicolumn{1}{c|}{2014} \\
\hline South Africa & 43,311 & 373,378 & 768,198 & 863,679 & 757,654 \\
\hline Mozambique & 11,331 & 24,303 & 46,412 & 37,365 & 63,966 \\
\hline China & 176,515 & 160,517 & - & - & 9,899 \\
\hline Zambia & 4,323 & 6,062 & 7,889 & 5,653 & 4,618 \\
\hline Botswana & 443 & 490 & 3,175 & 870 & 1,857 \\
\hline Malawi & 975 & 1,110 & - & 467 & 825 \\
\hline other & 241,157 & 152,184 & 906 & 380 & 1,398 \\
\hline Total tobacco exports '000' & 478,055 & 718,044 & 826,580 & 908,414 & 840,217 \\
\hline
\end{tabular}

* Sources: ITC calculations based on UN COMTRADE statistics

Suggested economic strategies to revive the cotton and tobacco production. In proposing the following policy measures and strategies, the researcher took into account the fact that cotton and tobacco crops are central towards the revival of the industrialisation process in Zimbabwe. In addition, unless exported as finished products, the crops suffer heavily from depressed international markets.

1. To ensure consistent and reliable supply of quality cotton yearly, the government should revive backward-and-forward linkages between cotton farmers and processors. This can be done in various forms:

$>$ Setting aside State farms (strategic farms) for the cultivation of cotton, whose output will guarantee the minimum industrial requirements. It may not necessarily be state farms per se, but identified individual cotton farmers devoted towards the production of this crop

> Promotion and facilitation by government of win-win contract farming in areas suitable for cotton growing. The government will act as a third party towards ensuring that both parties to the contract diligently adhere and benefit from the marriage. The Agricultural Extension Officers should provide both the technical and legal expertise required by farmers.

When the state is actively engaged and involved in the farming of cotton, it is easier to guarantee supply and to influence buying and selling prices. This suggested model demands that government enforces property rights and security of investment by private players.

2. The government should consider crafting cotton and tobacco buying and selling models. The minimum allowed buying price per kilogram must be at least the average cost per kilogram of production and must vary upwards with the quality of the crop.

3. There is need for government to institute some or all of the following:

$>$ Subsidise cotton and tobacco farmers to reduce production costs. This can take the form of subsidising the required inputs or issuance of farming financial grants. Where public resources have been committed, thorough follow-up, monitoring, evaluations, assessments and control measures must be instituted, with appropriate action taken basing on the outcome.

$>$ In case of strategic farming model, farmers must be given incentive backed quotas (minimum required output per farm/farmer). Incentives will vary from financial to nonfinancial-farm equipment, construction of farm infrastructure, exemption from certain statutory obligations, among others.

4. Cotton and tobacco research and development institutions must be equipped fully to ensure the fabrication of disease tolerant and highly productive crop varieties.

5. The country must prohibit the exportation of unmanufactured tobacco, raw cotton or even lint. This policy will warrant supply of adequate raw materials to downstream industries and promote value-addition of Zimbabwean export-bound output.

\section{CONCLUSION}

Persistent drop in tobacco buying prices, especially at the beginning of the selling season, will contribute extensively to the contraction of the industry in the near future. Most commercial and communal farmers will be forced by economic pressures (especially unreasonably low buying prices at auction floors and high input prices) to shun tobacco and 
cotton productions opting for other crops or income generating activities. Such actions will be detrimental to the recovery of the Zimbabwean economy as most downstream industries (thread, textile, chemical industries, oilseed making and cellulose and tobacco processing firms) will certainly collapse.

As long as the government is reluctant in instituting, enforcing and adhering to development oriented policies and strategies in the agricultural sector, the industrialisation process will not succeed. The gains of land reform process will never be realised. The principle hereby stated should be extended to other economic sectors, such as mining, to realise a prosperous Zimbabwe.

\section{REFERENCES}

1. Government of Zimbabwe, (2011), Medium Term Plan (2011-2015), Government of Zimbabwe

2. International Trade Centre (ITC), (2014), UN COMTRADE statistics - 07/06/2015

3. Moses Tekere, (2001), Trade liberalisation under structural economic adjustment Impact on social welfare in Zimbabwe, TRADES CENTRE

4. Ndlela D and Robinson P, (1992), Part II, Country Study, United Nations University

5. Zimbabwe Economic Policy and Research Unit, (2014), ZEPARU Occasional Research paper No.1/2014 